Acta vet. scand. $1986,27,280-295$.

From the Departments of Clinical Chemistry and Obstetrics and Gynaecology, Swedish University of Agricultural Sciences, Uppsala, Sweden.

\title{
SEQUENTIAL HORMONAL CHANGES IN THE POSTPARTUM DAIRY COW
}

\author{
By \\ A. Madej, H. Kindahl, K. Larsson and L.-E. Edqvist
}

\begin{abstract}
MADEJ, A., H. KINDAHL, K. LARSSON and L.-E. EDQVIST: Sequential hormonal changes in the postpartum dairy cow. Acta vet. scand. 1986, 27, 280 - 295. - Peripheral plasma levels of 15-keto-13,14dihydro-PGF $2 \alpha$, progesterone, cortisol, $\mathrm{LH}$ and prolactin were studied in 6 primiparous postpartum dairy cows. The cows were followed by hormone measurements and clinical examinations from parturition until pregnancy was established. Blood was collected 3 times per day. The cervix, uterus and ovaries were examined by rectal palpation at 6 - 10 days intervals. The cows were observed for signs of oestrus twice daily and were additionally teased with a bull to provoke standing heat.

Four cows had a normal parturition and dropped their fetal membranes shortly afterwards. (NR group). The remaining 2 retained their fetal membranes for more than $24 \mathrm{~h}$ following parturition (RFM group). One out of 6 cows showed standing oestrus at the first ovulation, 4 animals were in oestrus at the second ovulation and all cows showed signs of oestrus at the third ovulation. Although the length of the first luteal phase varied from 9 to 22 days a corpus luteum was in all cases palpated. The secretion of progesterone during the first luteal phase was terminated by a $\mathrm{PGF}_{2} \alpha$ release.

A significant difference in 15-keto-13,14-dihydro-PGF $2 \alpha$ levels between the 2 groups was found on days $0-4(2.39 \mathrm{vs} 6.87 \mathrm{nmol} / \mathrm{l}$ at $\mathrm{P}<0.06$ ). Postpartum prostaglandin $\mathrm{F}_{2 \alpha}$ release as reflected by the level of 15-keto-13,14-dihydro-PGF $2 \alpha$ lasted shorter in the NR group than in the RFM group ( $15-17$ vs 21 days). Significant positive correlations between 15-keto-13,14-dihydro-PGF $2 \alpha$ and cortisol as well as between prolactin and cortisol during the first 24 days postpartum were noted only in cows having normal parturition. The most pronounced daily prolactin variations occurred during the second luteal phase (NR group), when a significant difference between the times $8.00,12.00$ and 15.00 was recorded $(14.7,31.5$ and $19.7 \mu \mathrm{g} / \mathrm{l}$, respectively). Moreover, a partial negative correlation between log value of prolactin and arithmetical value of $\mathrm{LH}$ was found in these cows only during the first luteal phase after parturition.
\end{abstract}

15-ket o-13,14-dihydroprostaglandin $F_{2} \alpha$; progesterone; cortisol; luteinizing hormone; prolactin. 
The puerperium begins with the completion of parturition and terminates with the first fertile oestrus followed by normal corpus luteum life span (Malven 1984). Several more or less well defined hormonal events during the puerperium eventually leads to the onset of oestrus and ovulation.

A sustained release of prostaglandin $F_{2 \alpha}$ follows parturition and is in the cow reported to last for $1-4$ weeks (Edquist et al. 1976, 1978, Thatcher et al. 1980, Lindell et al. 1982, Madej et al. 1984a). In dairy cows peripheral plasma levels of LH increase during the early postpartum period (Kessler et al. 1979, Webb et al. 1980, Schallenberger et al. 1982) as does the anterior pituitary responsiveness to exogenous GnRH (e.g. Fernandes et al. 1978) and oestradiol-17 $\beta$ (Schallenberger \& Prokopp 1985). Resumption of ovarian activity, as reflected by elevated progesterone levels, following parturition in dairy cows is preceded by oestrus in $20-50 \%$ of the cases, a figure largely related to the frequency of observations (King et al. 1976, Larsson et al. 1984). The first postpartum elevation of progesterone has been considered either as a transient increase and of follicular origin (Tribble et al. 1973, Lamming \& Bulman 1976, van de Wiel et al. 1979, Stupnicki et al. 1980, Webb et al. 1980, Peters \& Lamming 1984) or as a short luteal phase caused by the formation of a corpus luteum, the lifespan of which is terminated prematurely (Schams et al. 1978, Manns et al. 1983).

The objective of this experiment was to study the sequential postpartum endocrine changes in carefully examined dairy cows. Part of the prostaglandin and progesterone data has been published previously in reviews (Kindahl et al. 1982, 1984).

\section{Experimental animals}

\section{MATERIAL AND METHODS}

Six primiparous dairy cows, crosses between Swedish Friesian and Swedish Red and White breeds were examined from parturition until conception, They were fed according to Swedish standards and milked twice daily. Rectal palpations were performed regularly at 6-10 days intervals. In the case of signs of vaginal discharge the vaginal mucosa and external cervical os were examined by vaginoscopy. All animals were checked for external signs of oestrus twice daily and if such signs were visible teasing with a bull was performed to test the presence of standing oestrus. 
The size of the uterus, its location, tone and symmetry were used as indicators of uterine involution. Involution was considered complete when the entire uterus was in the pelvic cavity, the uterine horns were of equal or almost equal size and no major enlargement of the uterine wall could be palpated. The day of ovulation was determined from a combination of clinical findings (presence of palpable corpus luteum), progesterone levels and postoestrous bleedings (day of ovulation $=$ the day before bleeding).

Blood samples were collected 3 times daily $(8.00,12.00$ and 15.00) from the jugular vein by venipuncture into heparinized glass tubes. The content of each tube was immediately centrifuged and the obtained plasma was kept at $-20^{\circ} \mathrm{C}$ until assayed.

\section{Radioimmunoassay}

Quantitation of progesterone, 15-keto-13,14-dihydro-PGF ${ }_{2 \alpha}$ (main metabolite of prostaglandin $F_{2 \alpha}$ ) and bovine LH in peripheral plasma was performed by radioimmunoassays that have been described in detail by Kindahl et al. (1976b) and Stupnicki \& Madej (1976), respectively. Prolactin contentrations were determinated by radioimmunassay (Schams 1974) with some modifications (Madej et al. 1985). The peripheral plasma levels of cortisol were measured by radioimmunoassay using an antiserum against cortisol-21-succinyl-BSA (Kula \& Stupnicki 1983) with modifications described by Nyberg et al. (1986).

All values presented represent the mean of duplicate determinations.

\section{Statistical methods and evaluation}

The analyses comprise simple statistic as well as the analysis of variance using the GLM procedure, and Scheffe's test available from the Statistical Analysis System (SAS 1982). All statistical calculations were performed using log values of 15-keto13,14-dihydro- $\mathrm{PGF}_{2 \alpha}$, cortisol and prolactin, and arithmetic value of LH.

The amount of $\mathrm{PGF}_{2 \alpha}$ released per $24 \mathrm{~h}$ during the immediate postpartum period was calculated from the mean of the 3 determinations of 15-keto-13,14-dihydro-PGF ${ }_{2 \alpha}$. The method of calculation was based upon the straight-line relation existing between the levels of 15-keto-13,14-dihydro- $\mathrm{PGF}_{2 \alpha}$ and the intravenously infused amount of $\mathrm{PGF}_{2 \alpha}$ (Kindahl et al. 1976a). 


\section{RESULTS}

\section{Clinical findings}

Four cows (nos. 1, 2, 3 and 5) were clinically healthy throughout the experiment and calved between 273 and 293 days after the last artificial insemination (NR group). The remaining 2 (nos. 4 and 6) had signs of respiratory disease at the end of gestation and calved on day 263 and 268, respectively. Both these cows retained their fetal membranes for more than $24 \mathrm{~h}$ (RFM group). The retained fetal membranes were removed on day 3 and 8 post partum, respectively. On day 13 cow no. 4 was found to have a purulent vaginal discharge and increased body temperature and was treated once with recommended doses of penicillin, streptomycin, and of cloprostenol, all injected intramuscularly. Some clinical data of the cows are presented in Table 1. Ovarian cyclicity was resumed in all cows between day 10 and 23 after parturition. Although the length of the first luteal phase varied from 9 to 22 days, a corpus luteum was in all cases palpated. One out of 6 cows (no. 4) showed standing oestrus at the first ovulation, 4 animals were in oestrus at the 2 nd ovulation and all cows showed signs of oestrus at the 3rd ovulation. In 3 of the cows postoestrous bleeding was seen in relation to the first ovulation and in the remaining 3 to the second ovulation. The time required to complete uterine involution varied in the 4 cows with normal puerperium from 20 to 25 days. In cows no. 4 and 6 with retained fetal membranes uterine involutions was completed on day 29 and 24, respectively. Four cows (nos. 2, 3, 4 and 5) became pregnant following artificial insemination on

T a b l e 1. Intervals from parturition to the 1st and 2nd postpartum ovulation, palpation of corpus luteum, 1st standing oestrus, 1st postoestrous bleeding, and time required to complete uterine involution.

\begin{tabular}{|c|c|c|c|c|c|c|}
\hline \multirow{2}{*}{$\begin{array}{l}\text { Cow } \\
\text { no. }\end{array}$} & \multicolumn{2}{|c|}{ Ovulation } & \multirow{2}{*}{$\begin{array}{l}\text { Palpation } \\
\text { of corpus } \\
\text { luteum }\end{array}$} & \multirow{2}{*}{$\begin{array}{l}\text { Standing } \\
\text { oestrus }\end{array}$} & \multirow{2}{*}{$\begin{array}{c}\text { Post- } \\
\text { oestrous } \\
\text { bleeding }\end{array}$} & \multirow{2}{*}{$\begin{array}{l}\text { Uterine } \\
\text { involution }\end{array}$} \\
\hline & 1 st & 2nd & & & & \\
\hline 1 & 10 & 20 & 15 & 41 & 12 & 25 \\
\hline 2 & 11 & 33 & 23 & 32 & 12 & 23 \\
\hline 3 & 23 & 32 & 31 & 55 & 33 & 20 \\
\hline $4^{\star}$ & 21 & 35 & 29 & 20 & 36 & 29 \\
\hline$\overline{5}$ & 12 & 29 & 20 & 27 & 13 & 25 \\
\hline $6^{\star}$ & 15 & 33 & 18 & 33 & 34 & 24 \\
\hline
\end{tabular}

* Cows with retained fetal membranes. 
day $52,55,56$ and 48 postpartum, respectively. The remaining 2 (nos. 1 and 6 ) became pregnant after day 90 post partum.

\section{Hormonal parameters}

Comparison of 15-keto-13,14-dihydro-PGF $2 \alpha$, cortisol, prolactin and LH concentrations between cows without and with retained fetal membranes is presented in Fig. 1. The early postpartum period has arbitrarily been divided into 5 days intervals. Significant differences in 15-keto-13,14-dihydro-PGF ${ }_{2 \alpha}$ levels between the two groups were found on days $0 \ldots 4$ (2.39 and 6.87 $\mathrm{nmol} / \mathrm{l}$, respectively, $\mathrm{P}<0.06)$ and on days $15-19(0.17$ and $0.46 \mathrm{nmol} / \mathrm{l}$, respectively, $\mathrm{P}<0.01)$. This significance was obtained when considering cow within group as the error term. In cows without retained fetal membranes the final decrease of 15-keto-13,14-dihydro-PGF ${ }_{2 \alpha}$ to the base levels $(0.17 \mathrm{nmol} / \mathrm{l})$ occurred on days 15-19 while in cows with retained fetal membranes a similar base level $(0.17 \mathrm{nmol} / \mathrm{l})$ was recorded on days 20-24 postpartum. In the case of cortisol a significant difference between groups was recorded on days 15-19, the levels being
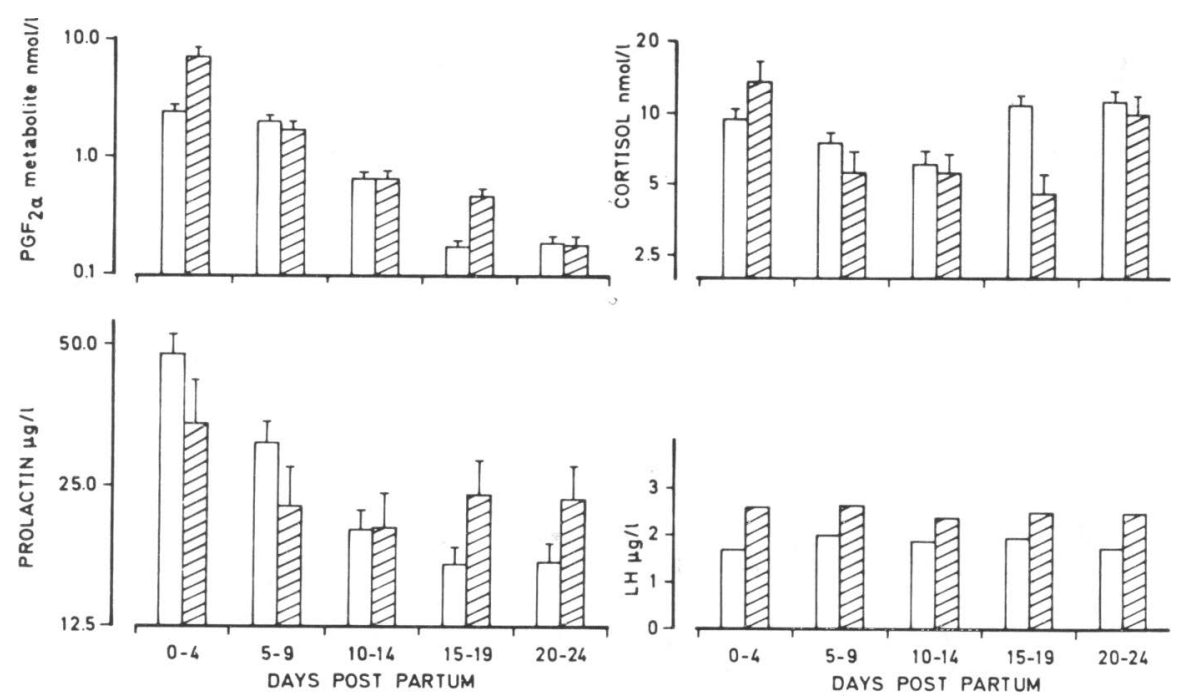

Figu re 1. Geometric means of 15-keto-13,14-dihydroprostaglandin $F_{2 \alpha}$, cortisol and prolactin together with their positive standards errors in the cows during the immediate postpartum period divided into 5 days intervals. Note: In the case of $\mathrm{LH}$ standard errors were very small and ranging from 0.06 to $0.07 \mu \mathrm{g} / 1$. Open bars represent cows without retained fetal membranes, hatched bars represent cows with retained fetal membranes. 
higher in cows without than in cows with retained fetal membranes $(10.7$ vs $4.6 \mathrm{nmol} / \mathrm{l}, \mathrm{P}<0.001)$. There was no significant difference in prolactin or in LH levels between groups. In cows without retained fetal membranes the least squares means of prolactin after parturition decreased significantly from 47.8 (days $0-4$ ) to $31.3 \mu \mathrm{g} / \mathrm{l}$ (days 5-9) and then to $20.2 \mu \mathrm{g} / \mathrm{l}$ (days 10-14). A significant difference in prolactin levels between days 0-4 and 10-14 was confirmed by Scheffe's test. In cows with retained fetal membranes no significant changes were noted during 24 days after parturition (comparing both least squares means and means by Scheffe's test). According to Scheffe's test no changes in $\mathrm{LH}$ concentrations during 24 days after parturition occurred in the 2 groups. However, in cows without retained fetal membranes the least squares means of LH increased significantly $(\mathrm{P}<0.01)$ from $1.64 \mu \mathrm{g} / \mathrm{l}$ (days $0-4)$ to $1.91 \mu \mathrm{g} / \mathrm{l}$ (days 5-9).

A partial positive correlation between cortisol and prolactin $(\mathrm{r}=0.34, \mathrm{P}<0.01)$ and between cortisol and 15-keto-13,14dihydroprostaglandin $\mathrm{F}_{2 \alpha}(\mathrm{r}=0.42, \mathrm{P}<0.01)$ during the first 24 days postpartum was recorded in cows without retained fetal membranes. In contrast, almost significant partial positive correlation between cortisol and prolactin $(\mathrm{r}=0.30, \mathrm{P}<0.1)$ and hardly any relation between cortisol and 15-keto-13,14-dihydroprostaglandin $F_{2 \alpha}$ were found in cows with retained fetal membranes.

Changes in concentration of 15-keto-13,14-dihydro-PGF ${ }_{2 \alpha}$ and progesterone in cow no. 5 during the immediate postpartum period are shown in Fig. 2. Plasma levels of 15-keto-13,14-dihydro-PGF ${ }_{2 \alpha}$ decreased from $23 \mathrm{nmol} / \mathrm{l}$ on day of parturition to $0.1 \mathrm{nmol} / \mathrm{l}$ on day 17 . Low levels of progesterone were maintained up to day 14 when it increased from approximately 0.5 nmol/l to its highest levels around $19 \mathrm{nmol} / \mathrm{l}$ on day 21 post partum. The first progesterone rise was terminated in conjunction with release of $\mathrm{PGF}_{2 \alpha}$ on day 25 post partum. In cow no. 3 (Fig. 3 ) the highest and the lowest 15-keto-13,14-dihydro-PGF ${ }_{2 \alpha}$ levels were recorded on day 4 and 17 post partum, respectively ( 8.0 vs $0.17 \mathrm{nmol} / 1)$. Low levels of progesterone were maintained for 24 days. Between days 25 and 30 progesterone exceeded $0.5 \mathrm{nmol} / \mathrm{l}$ with a maximum value of $4.7 \mathrm{nmol} / \mathrm{l}$. The secretion of progesterone during that short luteal phase was terminated by release of $\mathrm{PGF}_{2 \alpha}$ on day 29 post partum. At that time the concentrations 


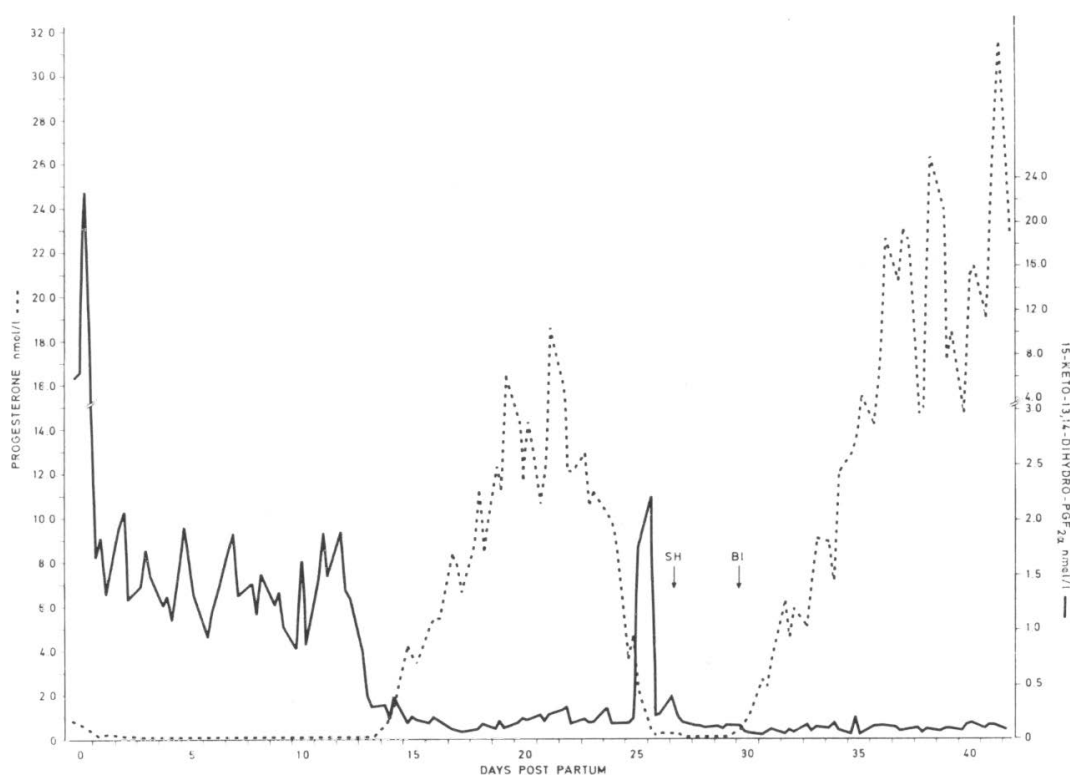

F i g u r e 2. Plasma levels of 15-keto-13,14-dihydroprostaglandin $\mathrm{F}_{2 \alpha}$ (solid line) and progesterone (dotted line) in cow no. 5 from day of parturition (day 0 ) and 42 days thereafter. Note: $\mathrm{SH}=$ standing heat, $\mathrm{Bl}=$ postioestrous bleeding.

of 15-keto-13,14-dihydro-PGF ${ }_{2 \alpha}$ increased to $1.5 \mathrm{nmol} / \mathrm{l}$. The remaining cows showed prostaglandin metabolite and progesterone profiles in between those of cows no. 5 and 3 . In no case

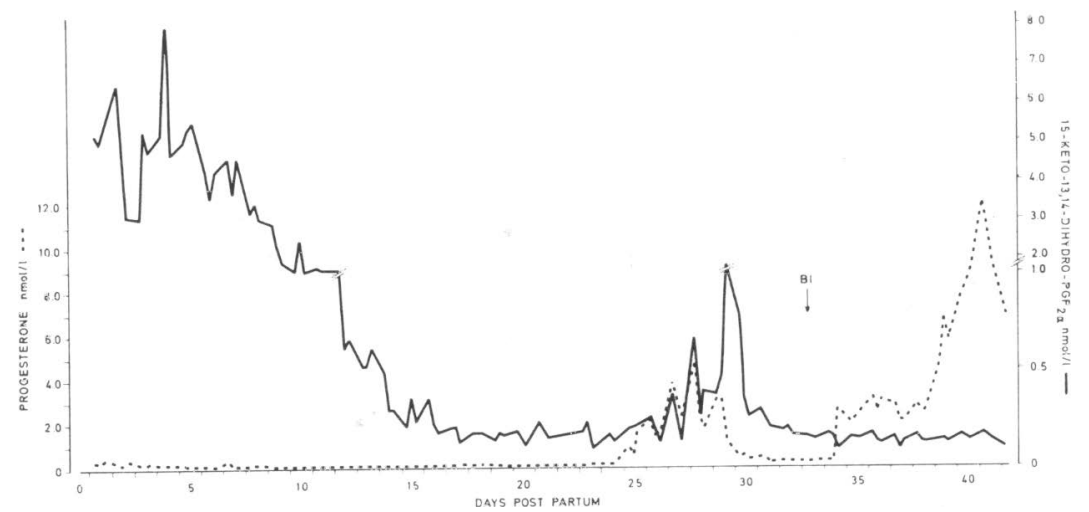

Figu re 3. Plasma levels of 15-keto-13,14-dihydroprostaglandin $F_{2 \alpha}$ (solid line) and progesterone (doted line) in cow no. 3 from day of parturition (day 0 ) and 42 days thereafter. Note: $\mathrm{Bl}=$ postoestrous bleeding. 


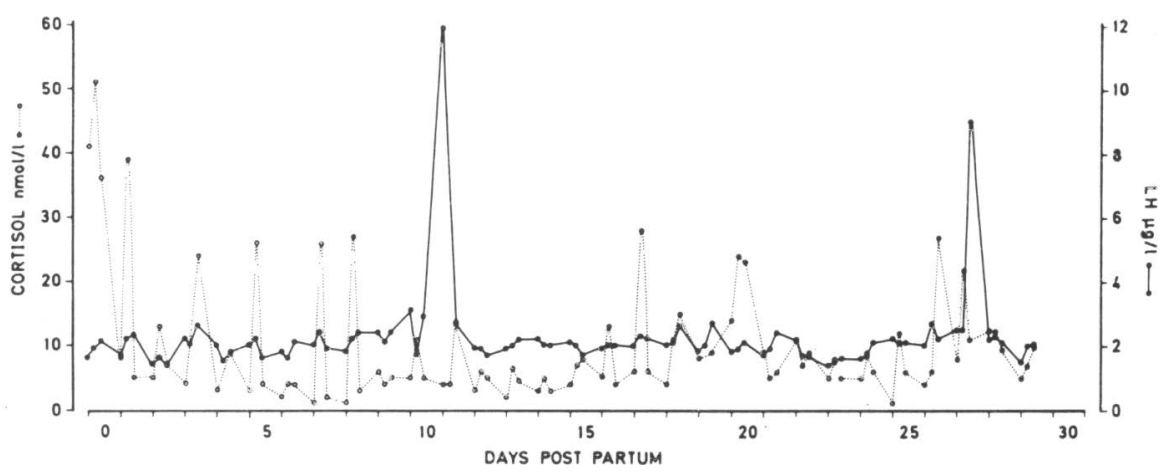

F i g u re 4. Plasma levels of LH (O-O) and cortisol (O-- - ) in cow no. 5 from day of parturition (day 0 ) and 29 days thereafter.

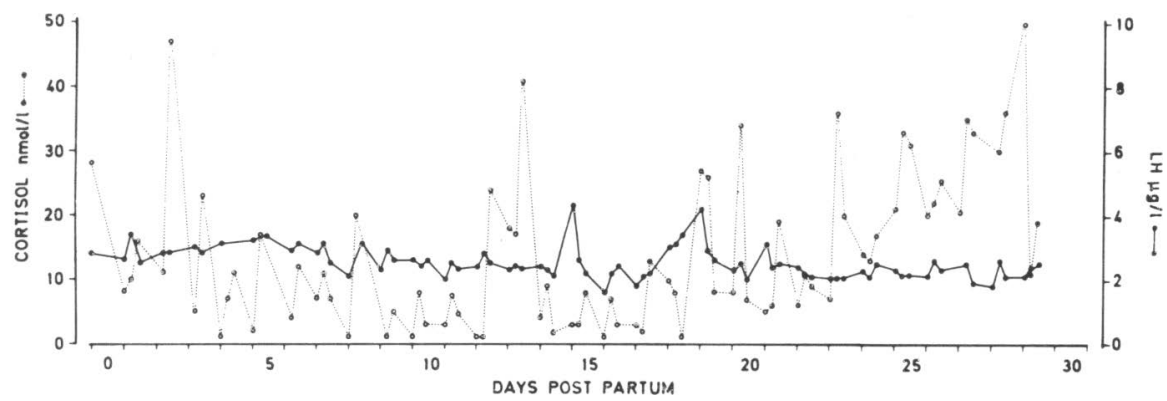

Figu re 5. Plasma levels of LH (- - and cortisol (O-- ) in cow no. 4 from day of parturition (day 0 ) and 29 days thereafter.

was a progesterone increase seen before the postpartum prostaglandin metabolite concentration had reached base level. In cow no. 5 representing the NR group an $\mathrm{LH}$ peak was observed on day 11 and another on day 27 (11.9 vs $7.9 \mu \mathrm{g} / \mathrm{l}$, Fig. 4). In both cases the LH surge preceded an elevation in progesterone and a palpable corpus luteum (see Fig. 2 and Table 1). The plasma levels of cortisol decreased after parturition and fluctuated thereafter around $1-28 \mathrm{nmol} / \mathrm{l}$ with a narrow range $(2--8 \mathrm{nmol} /$ 1) on days $12-15$ (Fig. 4 ). In cow no. 4 representing the RFM group two $\mathrm{LH}$ peaks exceeding $4 \mu \mathrm{g} / \mathrm{l}$ had been recorded on days 15 and 19 (Fig. 5) before the first ovulation occurred on day 21. The highest cortisol values were recorded on days 2 and 28 post partum (45 and $50 \mathrm{nmol} / \mathrm{l}$, respectively), while being rather low on days 9--11 and 14-16 ranging from 2 to $8 \mathrm{nmol} / \mathrm{l}$. 

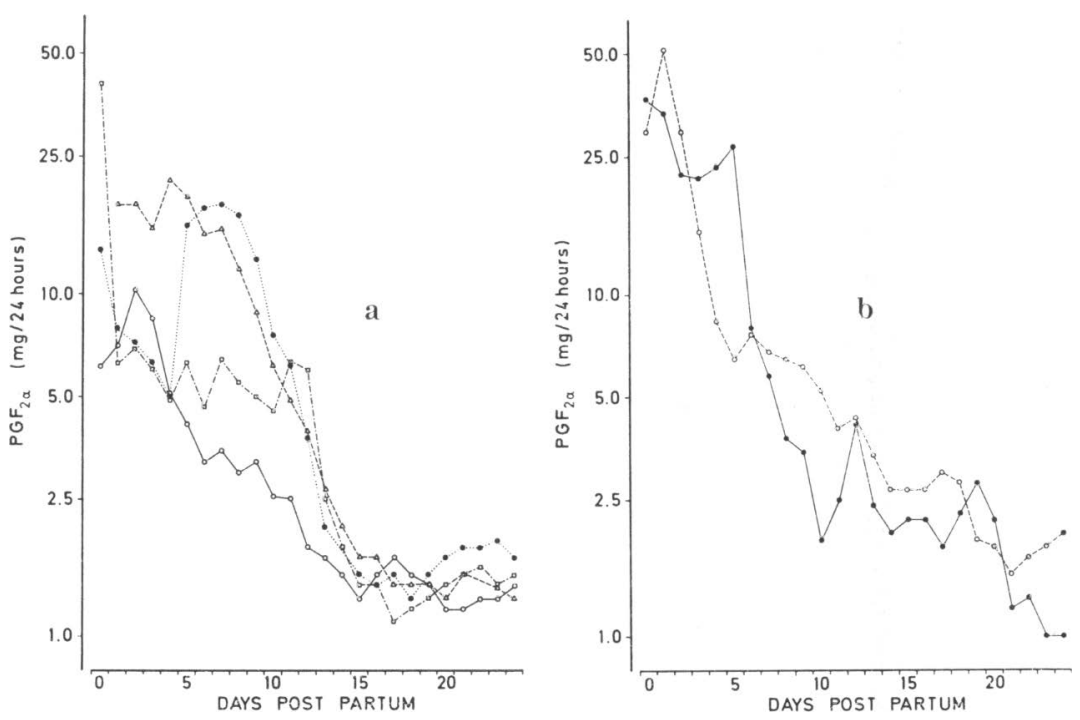

F i g u r e 6. Endogenous production of $\mathrm{PGF}_{2 \alpha}(\mathrm{mg} / 24 \mathrm{~h})$ in cows without retained fetal membranes (a) and in cows with retained fetal membranes (b) during the immediate postpartum period. Note: day $0=$ day of parturition.

A constant decrease of $\mathrm{PGF}_{2 \alpha}$ production from $6.2-41.0 \mathrm{mg}$ ' $24 \mathrm{~h}$ on day of parturition to $1.1-1.5 \mathrm{mg} / 24 \mathrm{~h}$ after $2-3$ weeks post partum is seen in Fig. 6a and Fig. 6b. When the 4 cows without retained fetal membranes (Fig. 6a) were compared with the 2 cows having retained fetal membranes (Fig. 6b), a difference in the duration of $\mathrm{PGF}_{2 \alpha}$ production could be seen (1517 vs 21 days).

In animals having a short luteal phase after the first ovulation (nos. 1, 3 and 4 ) the average progesterone ( \pm SEM) concentration was significantly $(P<0.05)$ lower on day 6 of that phase than on the same day of the second luteal phase which had normal length $(3.0 \pm 0.2$ vs $5.3 \pm 0.8 \mathrm{nmol} / \mathrm{l})$.

There was no difference between the average base LH levels before the first ovulation, during the first luteal phase and during the second luteal phase. However, in some cows a difference could be seen in the frequency of $\mathrm{LH}$ peaks above mean base level \pm 2 S.D. For instance, in cow no. 5 the first, second and third preovulatory LH peaks had been preceded by 1,0 and 5 extra LH peaks, respectively. 


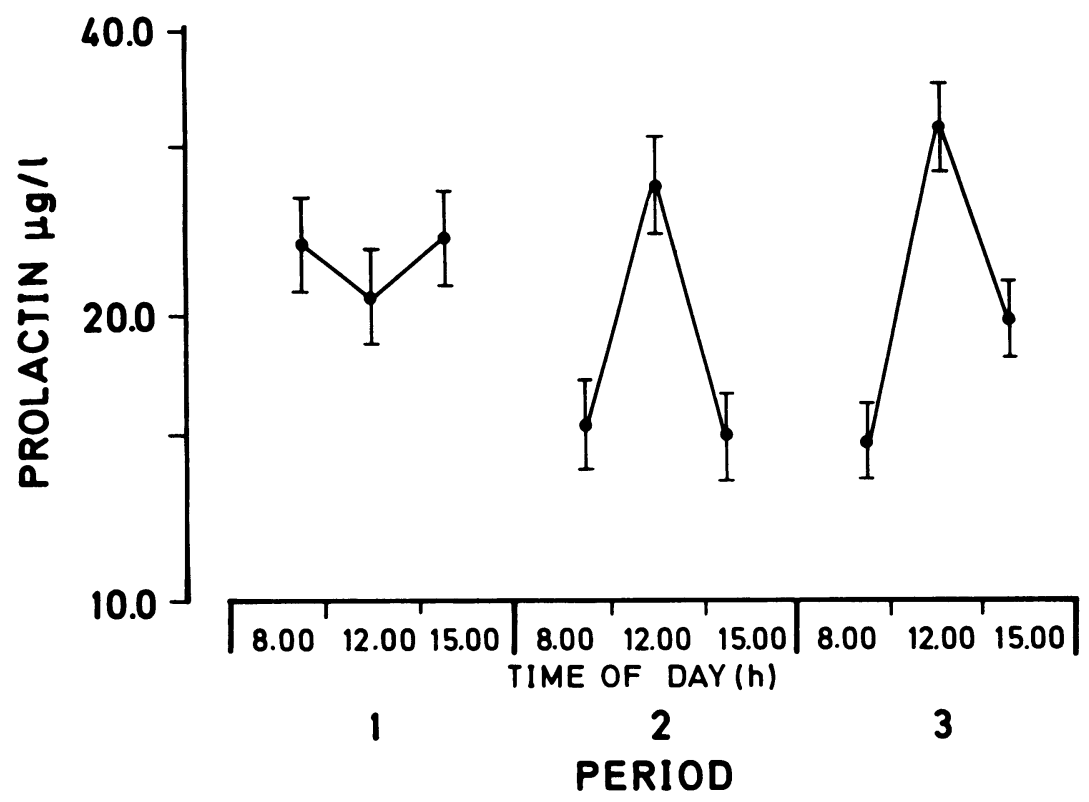

Figure 7. Geometric mean of prolactin at the different times of day during the immediate postpartum acyclic period (period 1), the first (period 2) and second luteal phase (period 3) in cows without retained fetal membranes.

No difference in daily prolactin secretion was found during the immediate acyclic period in cows without retained fetal membranes (Fig. 7). During the first luteal phase the highest least squares mean of prolactin was recorded at $12.00(27.4 \mu \mathrm{g} / \mathrm{l})$. The most pronounced prolactin variations occurred during the second luteal phase, when significant differences between $8.00,12.00$ and 15.00 were observed (14.7, 31.5 and $19.7 \mu \mathrm{g} / \mathrm{l}$, respectively). Furthermore, a negative partial correlation between log values of prolactin and arithmetical value of $\mathrm{LH}(\mathrm{r}=-0.19, \mathrm{P}<0.05)$ was found in these cows only during the first luteal phase after parturition.

In all cows that became pregnant progesterone levels remained high and no increase in 15-keto-13,14-dihydro-PGF ${ }_{2 \alpha}$ levels was seen.

\section{DISCUSSION}

The results of the present study are in agreement with earlier observations concerning the high incidence of shortlasting 
progesterone elevation before normal cyclicity is established in postpartum cows (Donaldson et al.1970, Robertson 1972, Schams et al. 1978, Webb et al. 1980). However, the present data do not support the view that this progesterone oomes from the follicles (e.g. Webb et al. 1980), because in all cases corpus luteum was palpated. Schams et al. (1978) reported that the preovulatory LH peak values had a tendency to increase with increasing number of cycles. Furthermore, Webb et al. (1980) found that the progesterone peak height was significantly lower in the first and short than in the third and normal oestrous cycle. The finding of lower progesterone levels on day 6 during the short cycle than on the same day during normal cycles is in agreement with the finding of Ramirez-Godinez et al. (1981). It is likely, however, that the luteolysis of the first postpartum corpus luteum is caused by $\mathrm{PGF}_{2 \alpha}$ release as reflected by 15 -keto-13,14-dihydro$\mathrm{PGF}_{2 \alpha}$ levels regardless of the length of the luteal phase. It should also be emphazised that this luteolytic release of $\mathrm{PGF}_{2 \alpha}$ was seen after the time when the postpartum release of prostaglandin $\mathrm{PGF}_{2 \alpha}$ had reached the base levels. On the other hand, Manns et al. (1983) suggested that in the first cycles which are shorter than about 15 days, although the corpus luteum may appear functionally normal, its life span is not terminated by the usual luteolytic processes, It is interesting to note that a large proportion of early ovulating cows had a short interval between the first and second ovulation (Larsson et al. 1984). In very recent studies (Fredriksson et al. 1985) the occurrence of short cycles could not be explained by the presence of bacteria in the uterus.

On indirect basis, estimates of daily production of $\mathrm{PGF}_{2 \alpha}$ during the postpartum period are in agreement with those measured directly by Guilbaut et al. (1984). According to these authors the measurements of 15-keto-13,14-dihydro-PGF ${ }_{2 \alpha}$ in the peripheral blood plasma is also a good indicator of a relative index of daily production of $F$ series prostaglandin in postpartum cows.

Out of the 6 cows studied here, 2 retained their fetal membranes. The results of the present study are in agreement with previous findings, viz. in cows with retained fetal membranes the duration of prostaglandin release was relatively long (Lindell et al. 1982, Fredriksson et al. 1985). In the present work, however, it was also shown that in cows with retained fetal mem- 
branes the levels of 15-keto-13,14-dihydro-PGF ${ }_{2 \alpha}$ were significantly higher than in normal cows during the immediate postpartum period. This accords with the findings of Bosu et al. (1984), who reported the concentrations of 15-keto-13,14-dihydroprostaglandin $F_{2 \alpha}$ on days 1,3 and 18 after parturition to be higher in cows with than in those without retained fetal membranes.

It should be emphasized that cloprostenol treatment in cow no. 4 most likely did not affect the postpartum profile of $\mathrm{PGF}_{2 \alpha}$ metabolite because of its very low cross-reaction in the radioimmunoassay of 15-keto-13,14-dihydro-PGF ${ }_{2 \alpha}$ (see Kindahl et al. 1981).

We could not find any significant difference in prolactin levels between cows having and cows not having retained fetal membranes as was reported by Chew et al. (1977). Instead there was a significant decrease of prolactin levels between days $0-4$ and $10-14$ in the postpartum cows not having retained fetal membranes. Conversely, this type of prolactin decreases did not occur in cows having retained fetal membranes. We have no good explanation for the positive correlation between 15-keto-13,14dihydroprostaglandin $F_{2 \alpha}$ and cortisol as well as between cortisol and prolactin in cows with normal parturition during the first 24 days postpartum and the lack of that relation in cows with retained fetal membranes.

The significant differences between prolactin secretion during the day with the highest levels at noon during the second luteal phase are similar to those found previously in cycling heifers (Madej et al. 1985).

The present data also do not exclude a relationship between LH and prolactin in postpartum milked cows. A negative relationship between the two hormones was recently suggested in postpartum suckling cows (Madej et al. 1984b).

\section{ACKNOWLEDGEMENTS}

This work and the position of A. Madej were supported by grants from the Swedish Council for Forestry and Agricultural Research.

\section{REFERENGES}

Bosu, W. T. K., R. M. Liptrap \& K. E. Leslie: Peripheral changes in plasma progesterone and 15-keto-13,14-dihydroprostaglandin $\mathrm{F}_{2 \alpha}$ concentrations in Holstein cows with or without retained foetal membranes. Anim. Reprod. Sci. 1984, 7, 497-510. 
Chew, B. P., H. F. Keller, R. E. Erb \& P. V. Malven: Periparturient concentration of prolactin, progesterone and the estrogens in blood plasma of cows retaining and not retaining fetal membranes. J. Anim. Sci. 1977, 44, 1055-1060.

Donaldson, L. E., J. M. Bassett \& G. D. Thourburn: Peripheral plasma progesterone concentration of cows during puberty, oestrous cycles, pregnancy and lactation, and the effects of undernutrition or exogenous oxytocin on progesterone concentration. J. Endocr. 1970, 48, 599-614.

Edqvist, L.-E., H. Kindahl \& G. H. Stabenfeldt: On the role of prostaglandins in bovine parturition. Proc. VIIIth Int. Congr. on Animal Reproduction and Artificial Insemination, Cracow, Poland 1976, vol. III, p. 357-360.

Edqvist, L.-E., H. Kindahl \& G. Stabenfeldt: Release of prostaglandin $\mathrm{F}_{2 \alpha}$ during the bovine peripartal period. Prostaglandins 1978, $16,111-119$.

Fernandes, L. C., W. W. Thatcher, C. I. Wilcox \& E. P. Call: LH relase in response to $\mathrm{GnRH}$ during the postpartum period of dairy cows. J. Anim. Sci. 1978, 46, 443-448.

Fredriksson, G., H. Kindahl, K. Sandstedt \& L.-E. Edqvist: Intratrauterine bacterial findings and release of $\mathrm{PGF}_{2 \alpha}$ in the postpartum dairy cow. Zbl. Vet. Med. A 1985, 32, 368-380.

Guilbault, L. A., W. W. Thatcher, D. B. Foster \& D. Caton: Relationship of 15-keto-13,14-dihydro-prostaglandin $F_{2 \alpha}$ concentrations in peripheral plasma with local uterine production of $F$ series prostaglandins and changes in uterine blood flow during the early postpartum period of cattle. Biol. Reprod. 1984, 31, 870878.

Kesler, D. J., H. A. Garverick, C. J. Bierschwal, R. G. Elmore \& R. S. Youngquist: Reproductive hormones associated with normal and abnormal changes in ovarian follicles in postpartum dairy cows. J. Dairy Sci. 1979, 62, 1290-1296.

Kindahl, H., L.-E. Edqvist, A. Bane \& E. Granström: Blood levels of progesterone and 15-keto-13,14-dihydro-prostaglandin $\mathrm{F}_{2 \alpha}$ during the normal oestrous cycle and early pregnancy in heifers. Acta endocrinol. (Copenh.) 1976a, 82, 134-149.

Kindahl, H., L.-E. Edqvist, E. Granström \& A. Bane: The release of prostaglandin $\mathrm{F}_{2 \alpha}$ as reflected 15-keto-13,14-dihydroprostaglandin $\mathrm{F}_{2 \alpha}$ in the peripheral circulation during normal luteolysis in heifers. Prostaglandins 1976b, 11, 871-878.

Kindahl, H., J.-O. Lindell \& L.-E. Edqvist: Release of prostaglandin $\mathrm{F}_{2 \alpha}$ during the oestrous cycle. Acta vet. scand. 1981, Suppl. 77, $143-158$.

Kindahl, H., L.-E. Edqvist, K. Larsson \& A. Malmqvist: Influence of prostaglandins on ovarian function post partum. In: Karg, $\mathrm{H}$. \& E. Schallenberger (ed.): Factors influencing fertility in the postpartum cow. Current Topics in Veterinary Medicine and Animal Science 1982, 20, 173-196.

Kindahl, H., G. Fredriksson, A. Madej \& L.-E. Edqvist: Role of prosta- 
glandins in uterine involution. Proc. 10th Int. Congr. on Animal Reproduction and Artificial Insemination, Illinюis, USA 1984, vol. IV, XI-9-XI-16.

King, G. J., I. P. Hurnik \& H. A. Robertson: Ovarian function and estrus in dairy cows during early lactation. J. Anim. Sci. 1976, $42,688-692$.

Kula, E. \& R. Stupnicki: Direct radioimmunoassay of cortisol in plasma. Zeszyty Problemowe Postepów Nauk Rolniczych 1983, 261, 75 (Abstr.).

Lamming, G. E. \& D. C. Bulman: Use of milk progesterone radioimmunoassay in the diagnosis and treatment of subfertility in dairy cows. Brit. vet. J. 1976, 132, 507-517.

Larsson, K., L. Jansson, B. Berglund, L.-E. Edqvist \& H. Kindahl: Postpartum reproductive performance in dairy cows. I. Influence of animal, breed and parity. Acta vet. scand. 1984, 25, 445-461.

Lindell, J.-O., H. Kindahl, L. Jansson \& L.-E. Edqvist: Post-partum release of prostaglandin $\mathrm{F}_{2 \alpha}$ and uterine involution in the cow. Theriogenology 1982, 17, 237-245.

Madej, A., L.-E. Edqvist, H. Kindahl \& G. Ekbohm: Circadian rhythm of plasma prolactin in heifers. Zbl. Vet. Med. A 1985, 32, 419427.

Madej, A., H. Kindahl, W. Woyno, L.-E. Edqvist \& R. Stupnicki: Blood levels of 15-keto-13,14-dihydro-prostaglandin $F_{2 \alpha}$ during the postpartum period in primiparous cows. Theriogenology 1984a, 21, 279-287.

Madej, A., E. O. Oyedipe, L.-E. Edqvist \& H. Kindahl: Prolactin and LH in postpartum suckling cows. Proc. 10th Int. Congr. on Animal Reproduction and Artificial Insemination, Illinois, USA 1984 b, vol. III, p. 403.

Malven, $P$. V.: Pathophysiology of the puerperium: definition of the problem. Proc. 10th Int. Congr. on Animal Reproduction and Artificial Insemination, Illinois, USA 1984, vol. IV, III-1-III-8.

Manns, J. G., W. D. Humphrey, P. F. Flood, R. J. Mapletoft, N. Rawlings \& $K$. W. Cheng: Endocrine profiles and functional characteristics of corpora lutea following onset of postpartum ovarian activity in beef cows. Canad. J. Anim. Sci. 1983, 63, 331-347.

Nyberg, L., A. Madej \& A. Kunavongkrit: Binding capacity of cortisol binding globulin and circulating free cortisol in postpartum sows. 1986. Submitted for publication.

Peters, A. R. \& G. E. Lamming: Reproductive activity of the cow in the post-partum period. II. Endocrine patterns and induction of ovulation. Brit. vet. J. 1984, 140, 269-280.

Ramirez-Godinez, J. A., G. H. Kiracofe, R. M. McKee, R. R. Schalles \& $R$. J. Kittok: Reducing the incidence of short estrous cycles in beef cows with Norgestomet. Theriogenology 1981, 15, 613623.

Robertson, H. A.: Sequential changes in plasma progesterone in the cow during the estrous cycle, pregnancy, at parturition, and post partum. Canad. J. Anim. Sci. 1972, 52, 645-658. 
SAS Institute Inc.: SAS User's Guide: Statistics. SAS Institute Inc., Cary N.C. 1982, pp. 139-199.

Schallenberger, E., U. Oerterer \& G. Hutterer: Neuroendocrine regulation of postpartum function. In: Karg, H. \& E. Schallenberger (ed.): Factors influencing fertility in the postpartum cow. Current Topics in Veterinary Medicine and Animal Science 1982, 20, 123-147.

Schallenberger, E. \& S. Prokopp: Gonadotrophins and ovarian steroids in cattle. IV. Re-establishment of the stimulatory feedback action of oestradiol-17 $\beta$ on LH and FSH. Acta endocrinol. (Copenh.) 1985, 109, 44-49.

Schams, D.: Untersuchungen über Prolaktin beim Rind. (Studies on prolactin in the cow). Fortschritte in der Tierphysiologie und Tierernährung $1974,5,1-125$.

Schams, D., E. Schallenberger, Ch. Menzer, I. Stangl, K. Zottmeier, B. Hoffmann \& H. Karg: Profiles of LH, FSH and progesterone in postpartum dairy cows and their relationship to the commencement of cyclic functions. Theriogenology 1978, 10, 453-468.

Stupnicki, R. \& A. Madej: Radioimmunoassay of LH in blood plasma of farm animals. Endokrinologie 1976, 68, 6-13.

Stupnicki, R., A. Madej, W. Woyno, Z. Binienda \& B. Barcikowski: Progesterone changes in postpartum uniparous cows. Proc. 9th Int. Congr. on Animal Reproduction and Artificial Insemination, Madrid, Spain 1980, vol. IV, p. 48-51.

Thatcher, W. W., Ch. J. Wilcox, R. J. Collier, D. S. Eley \& H. H. Head: Bovine conceptus - Maternal interactions during the pre- and postpartum periods. J. Dairy Sci. 1980, 63, 1530-1540.

Tribble, R. L., A. M. Sorensen jun., T. L. Woodward, J. S. Connor, J. R. Beverly \& J. L. Fleeger: Serum progestins and luteinizing hormone levels in non-suckled primiparous heifers. Nature 1973, $246,494-495$.

van de Wiel, D. F. M., C. H. J. Kalis \& S. N. H. Shak: Combined use of milk progesterone profiles, clinical examination and oestrus observation for the study of fertility in the post-partum period of dairy cows. Brit. vet. J. $1979,135,568-577$.

Webb, R., G. E. Lamming, N. B. Haynes \& G. R. Foxcroft: Plasma progesterone and gonadotrophin concentrations and ovarian activity in post-partum dairy cows. J. Reprod. Fert. 1980, 59, 133-143.

\section{SAMMANFATTNING}

\section{Hormonförändringar hos mjölkkor efter förlossningen.}

På 6 mjölkkor, förstagångskalvare, studerades de perifera plasmanivåerne av 15-keto-13,14-dihydro- $\mathrm{PGF}_{2 \alpha}$, progesteron, kortisol, LH och och prolaktin efter förlossningen. Hormonmätning och klinisk undersökning gjordes fortlöpande under tiden från förlossningen till dess att ny dräktighet kunde konistateras. Blodprover samlades 3 gånger per dag. Cervix, uterus och äggstockar undersöktes genom rek- 
talpalpation var 6-10 dag. Två gånger per dag gjordes observationer för att konstatera brunst och i närvaro av tjur testades ståreflexen.

Fyra av korna hade normal förlossning, och efterbörden avgick efter kort tid (NR-gruppen). De 2 övriga hade kvarbliven efterbörd i mer än ett dygn efter förlossningen (RFM-gruppen). En av 6 kor uppvisade ståbrunst vid den första ovulationen, 4 djur visade brunst vid den andra ovulationen, och alla djur visade tecken på brunst vid den tredje ovulationen. Längden på den första lutealfasen varierade mellan 9 och 22 dagar, men i samtliga fall kunde en gulkropp palperas. Progesteronproduktionen under den första lutealfasen avslutades $i$ och med att $\mathrm{PGF}_{2 \alpha}$ började frisättas.

Det påvisades en signifikant skillnad i 15-keto-13,14-dihydro$\mathrm{PGF}_{2 \alpha}$-nivå mellan de 2 grupperna dag $0 \_4 \quad(2,39 \mathrm{resp} 6,87 \mathrm{nmol} / \mathrm{l}$, $\mathrm{P}<0,06)$. Frisättningen av prostaglandin $\mathrm{F}_{2 \alpha}$ post partum varade längre i RFM-gruppen än i NR-gruppen (21 resp 15-17 dagar). Under de första dagarna påvisades en signifikant positiv korrelation mellan 15-keto-13,14-dihydro-PGF ${ }_{2 \alpha}$ och kortisol liksom mellan prolaktin och kortisol hos de kor som hade normal förlossning. De mest uttalade dygnsvariationerna för prolaktin inträffade under den andra lutealfasen (NR-gruppen), när en signifikant skillnad noterades mellan klockslagen $8.00,12.00$ och 15.00 (14,7 resp 31,5 och $19,7 \mu \mathrm{g} / \mathrm{l})$. Vidare noterades en partiell negativ korrelation mellan prolaktinets logvärde och det aritmetiska LH-värdet hos dessa kor, men bara under den första lutealfasen efter förlossningen.

(Received March 20, 1986).

Reprints may be requested from: Andrzej Madej, the Department of Clinical Chemistry, Faculty of Veterinary Medicine, Swedish University of Agricultural Sciences, Box 7038, S-750 07 Uppsala, Sweden. 